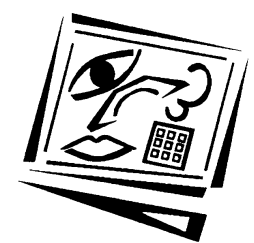

\title{
Facilitating digital video production in the language arts curriculum
}

\author{
Susan McKenney and Joke Voogt \\ University of Twente
}

\begin{abstract}
Two studies were conducted to facilitate the development of feasible support for the process of integrating digital video making activities in the primary school language arts curriculum. The first study explored which teaching supports would be necessary to enable primary school children to create digital video as a means of fostering communications skills. A pupil workbook was determined to be the most appropriate solution, and a draft workbook was piloted. The second study evaluated how well the learner workbook, when combined with a teacher guide and an introductory workshop, contributed to supporting the process of digital video making for the purpose of fostering message design competencies. This article describes motives for linking video making to the language arts curriculum, as well as how those ideas and the study data informed the development of the primary means of support - the pupil workbook.
\end{abstract}

\section{Background}

Research into writing has come to emphasise writing not as an individual, productoriented activity, but as a social, process-oriented activity (Hillocks, 1986, 1999; Nystrand, Gamaron, Kachur \& Prendergast, 1997; Peterson, 2003; van den Ven, 1993) that stresses the critical relationship between writing and other language processes, such as reading, speaking and listening (Sperling, 1996). Not only do children compose for an audience, but their (re)writings are fed by comments from teachers and peers in a social context (Wong \& Berninger, 2004). Translating this perspective into educational practice proves demanding for Dutch teachers. Improving Dutch language education practice has been a topic of increasing attention in the last decade. This has been evidenced by parliamentary decisions for educational funding to target language program development, as well as the establishment of a national centre for Dutch language studies in the late 1990s, whose mission is to help shape 'interactive language teaching' in Dutch schools. The study described here explored how to support the process of digital video-making as a means to develop writing skills, together with broader communications skills, in primary school classrooms.

\section{Theoretical underpinnings}

Teaching pupils how to design a message - whether written or verbal, in print or on screen - can be difficult. The skills that are addressed in creating a video message are similar to those needed to create a written piece or prepare a presentation. Besides being highly motivating for students, creating videos can also afford valuable opportunities to develop communications skills. This is a function of the fact that: (a) learning facilitated by technology is a social activity where pupils share, discuss and 
collaborate; and (b) the message design process is similar regardless of the medium chosen. The following text describes the theoretical underpinnings for this perspective, and emphasises that support is necessary for realising the educative potential embodied in the process of video-making.

\section{Language learning and media production}

From the interactive perspective, language arts education should be social, meaningful and intentional. Additionally, primary school language development should be integrated in such a way that it helps to practice thinking processes (SLO, 2007). One thinking process that clearly links to language development is that of message design. The message design process requires certain steps in the thinking and production: (1) formulating a message goal; (2) considering the audience; (3) mapping necessary elements; (4) collecting and organising content; (5) reducing the elements to the essentials (editing and revising); and (6) publication. While these remain similar, regardless of the medium used (audio, video, text, etc.) (cf. Babaszweski, 2002; Hernández-Ramos, 2007; Lee, McLoughlin \& Chan, 2008; Kearney \& Schuck, 2006), specific connections between the media development process and the writing process are beginning to receive attention in the literature (Hofer \& Owings-Swan, 2005; Hoffenberg \& Handler, 2001; Reid, Burn \& Parker, 2002; Kearney \& Schuck, 2006).

\section{Media development and collaboration}

Engaging students in the development of media products has been cited as a powerful way to promote individual and collective learning (Lee et al., 2008), and to establish a sense of community within the classroom (Babaszweski, 2002), possibly even helping to bridge social boundaries and class barriers (Reid et al., 2002). While the target audience is one important factor influencing a message design, research has shown that, when it comes to media development in classrooms, peer audiences exert additional influences. Peer audiences provide extrinsic motivation and stimulate learners to remain interested, actively engaged and on task. When creating work to be presented among peers, pupils (more) critically analyse their own work before sharing it with others (Schuck \& Kearney, 2006; Reid et al., 2002). In his article on Internetbased collaborative projects published over a decade ago, Windschitl (1998, p. 28) aptly noted that the vast majority of literature contains descriptions and intuitive analyses, but "stops short of asking critical questions such as: Are these practices helping students and if so, how?" Since then, the added value of collaborative projects has become increasingly addressed in research and literature. The following section examines how collaborative digital video projects can help children learn.

\section{DV production in schools}

The use of digital video as a communication tool to facilitate students' communication of a message, idea or information is highly motivating for students (Burden \& Kuechel, 2004; Hoffenberg \& Handler, 2001; Hooper \& Rieber, 1995; Kearney \& Schuck, 2006) and engenders their commitment (Babaszweski, 2002; Kearney \& Schuck, 2006). While varied aspects of digital video creation contribute to student motivation, one aspect pertains to the opportunities it can offer to ground student work in meaningful contexts, a known principle of effective instruction (cf. Hooper \& Rieber, 1995). Review of research that identifies specific learning goals related to video production (Babaszweski, 2002; Christi et al, 2004; Reid et al, 2002; Kearney \& Schuck, 2006; Theodosakis, 2002) shows that such goals may be divided into two broad categories: 
substantive and procedural. The substantive category includes subject matter content areas addressed in the message designed. The procedural goals relate to knowledge and skills learned through the video-making process. Three types of process-related knowledge and skills may be distinguished: communication knowledge and skills (e.g. storytelling, expression/voice, logic/analysis, and structure); collaboration knowledge and skills (e.g. identification of group goals, teamwork and affective skills); and project management knowledge and skills (e.g. time budgeting and management, organisation, planning and logistics).

\section{Video-making and teachers}

International research in the last decade has documented so many barriers to technology use in education that one might begin to wonder how technology has ever made its way into classrooms at all. For a minority, an interest in the medium or thrill of the challenge is sufficient reason to tackle projects involving technology use. But for the majority of educators, technology becomes worth the hassle when the added value for student learning is apparent. Scholarship in the design and effectiveness of specific technologies offers important contributions to understanding how technology can promote pupil learning (e.g. Dede, 2008). In addition, teachers' attitudes and competencies towards technology are important for technology integration (Knezek \& Christensen, 2008). Initial positive experiences, in this case with video-making, can also help to reduce fear and anxiety about technology integration (Hernández-Ramos, 2007).

To help facilitate initial positive experiences and further contribute to facilitating innovation in the curriculum, the role of lesson materials - especially those that illustrate desired practice (exemplary materials) - can be significant. Van den Akker (1998) summarises three main advantages offered by exemplary materials:

- clearer understanding of how to translate curriculum ideas into classroom practice;

- concrete foothold for execution of lessons that resemble the original intentions of the designers;

- stimulation of reflection on one's own role with the eventual possibility of adjusting one's own attitude toward the innovation.

Similar benefits of the role of materials have been identified by other researchers (Ball \& Cohen, 1996; Vooght, 1997; Thijs, 1999).

While some practical guides are available for teachers wishing to engage in classroom video production (Anderson, 2002; Babaszweski, 2002; Greenwood, 2007; Reid et al., 2002), few are grounded in research, although Kearney and Schuck's (2006) model of good practice is a notable exception. The severe lack of research-based support materials for incorporating video-making activities into the classroom was a main driving force behind the innovation and flanking research. When it comes to integrating video-making into the language arts curriculum, no other support materials, in English or in Dutch, have been located after extensive searching in both research and practice publications. Therefore, the LIVE (Language Instruction through Video-making Experiences) research and development project was initiated to fill this gap. The studies presented in the following section focus on the characteristics of the supports (mainly learner workbooks) that were created as a pre-requisite to being able to explore the potential added value of language learning through video-making. 


\section{Research and development approach}

\section{About the innovation}

The ultimate goal of the LIVE project was to explore the potential for enhancing language instruction in the upper grades of primary school by engaging pupils in the creation of digital videos. Given the complexities associated with digital video-making in classrooms, an explicit interim goal was to explore ways of supporting the implementation of digital video-making. Two schools were selected to participate in the LIVE project, on the basis of three criteria: (1) natural links between this project and ongoing school activities were readily identifiable; (2) the schools demonstrated interest in exploring new pedagogical uses of technology; and (3) the schools were, themselves, willing to invest in the effort (in the forms of hardware, software and/or teacher time).

\section{Learning goals}

Based on the learning potentials associated with media production and development (described in the previous section) as well as an analysis of national targets for advanced literacy, three sets of project goals were established. The primary emphasis was on strategic message design, in which pupils would learn strategies to produce meaningful and functional messages. A secondary goal was to foster reflections on communicative artifacts, towards better understanding of the functions and types of messages.

\section{Flanking research}

As previously stated, the LIVE project ultimately aimed to explore the potential addedvalue of digital video-making as a vehicle for language instruction, toward reaching the learning goals presented above. But research on curriculum innovation in general and technology integration in particular teaches us that the way in which new ideas and approaches are implemented can largely determine the extent to which their added-value is realised (or not). Too often, the merits of curricular innovations are evaluated too soon - before teachers and pupils have had sufficient time and support to actually enact them as desired. For this reason, two phases of research and development have been defined. The first phase focused on facilitating the envisioned activities, with flanking research examining support for the process of digital videomaking. In the second phase, which is currently underway, attention centres on the learning processes and outcomes resulting from participation in the LIVE project. This includes exploring ways of transferring message design competencies obtained through video-making to the creation of written products.

This article only reports on the first phase of the project: establishing the pre-requisite supports that will allow implementation (and study) of language learning through video-making. Research conducted within the first phase was divided into two studies. Both studies relate to supporting a process through which learners create 2-3 minute informational videos, each with a clear message and an introduction-body-conclusion structure. The first study was a pilot; and it focused on selecting and drafting forms of support for digital video-making. Based on the results from the first study, three supports were redeveloped: a teacher guide, a teacher workshop, and a learner workbook. The second (main) study evaluated the support that had been developed, focusing specifically on the learner workbook. 


\section{Pilot study: Focusing the support}

\section{Questions and methods}

The pilot study was guided by the following main research question, "What teaching and learning supports are necessary to enable primary school children to create digital video as a means to fostering communications skills?" Two types of data were collected to answer this question: data about the context; and data about the potential supports. Data on the context were collected by site visits to each of the two schools, interviews with administrative staff and questionnaires from nearly all the teachers $(n=28)$. This information was used to shape the first support: a learner workbook. Data on the learner workbook were collected through observation of pupils $(n=22)$ during the use of workbook prototypes as well as analysis of the videos created $(n=11)$. From each class in the pilot sessions $(n=5)$, the teachers selected one or two pairs of children to participate. While no specific selection criteria were used, several teachers mentioned that they had decided to select children who "don't usually get the chance to do extra things like this."

\section{Findings}

Data pertaining to the LIVE project context included the individual and school-wide views toward both language development and technology use, as well as teacher attitudes toward video-making by pupils. Further, school and classroom facilities were examined. The context data offered insight into the existing opportunities and constraints that would shape the video-making project. Opportunities to capitalise on included: high appeal of video-making to pupils; video-making was seen as interesting and new by most teachers; and the process was perceived as relatively easy to connect to other classroom activities. Constraints within which the innovation would have to work included: limited teacher technical expertise; limited teacher time for guiding children; average of two computers per classroom; one video camera per school; and clumsy systems for publication and presentation (Internet and data projection facilities not yet streamlined). Before the LIVE project, teachers had not conducted videomaking activities in their classes at all, and they were aware of no materials or other forms of support available for this purpose. These opportunities and constraints listed above prompted the decision to create support in the form of a learner workbook. The workbook was to be usable with minimal instruction from the teacher, by small groups of children who could take turns using the computers and camera.

Two successive prototypes of the workbook were created and piloted with children from grades 4 through 6 . While the workbook was usable, observations during the use of the workbooks led to two main types of improvements: clarity and chunking. Clarity refers to how easily the ideas are understood by the reader. Ideas presented in the first version of the workbook were more abstract; clarity was increased in the second version by re-writing the lesson goals and outputs, and adding concrete examples for both. Chunking pertains to the clusters and breaks within a module of learning. The double-lessons and lessons spread across working sessions proved less feasible. It was more difficult for teachers to organise double-lessons than had been anticipated. And the start-up time and effort were deemed too great for lessons that picked up where a previous session had ended more than a day before. Single-lessonsized chunks of 45 minutes each worked best. Pupils were able to build upon previous work without having to repeat the line of thinking that had been elaborated in earlier sessions. This was both motivating and efficient. 
Observation data allowed for more realistic estimations of time needed, but rechunking the content remained a challenging endeavour. Deciding what to keep and eliminate forced trade-off decisions and more careful analysis of which activities contributed most to the goals of the project. For example, in choosing how much time to allot for editing in transitions between clips versus layering subtitles on top of clips, the latter was given preference because it is more likely to contribute to the message focus. Pupil observation as well as analysis of the videos made yielded several additional insights that were used in designing the teaching and learning supports for the second phase (main study). First, most of the activities were carried out without the aid of the teacher. However, when help was requested, it was clear that the youngest children (grade 4) needed substantially more encouragement and assistance, and, when help was needed, teachers were not immediately prepared with the knowledge of how to do so. The observation and video analysis data from the pilot sessions contributed to the design of the final teaching and learning supports. In addition to an improved learner workbook, an introductory workshop for teachers as well as a teacher guide were developed. The workshop and teacher guide were added to enable teachers to easily speak to learner questions during use of the workbook; the original goals of working nearly independently remained intact.

\section{Main study: Learner workbook evaluation}

In the second phase of research and development, the teacher workshop and guidebook were created to aid in the implementation of the learner workbook. Understanding how well the learner workbook contributed to supporting the process of digital video-making for the purpose of fostering message design competencies was the focus of the main study. The research questions addressed in the main study were:

1. How was the learner workbook intended to be used and actually used in the classroom?

2. What is the quality of the video messages made by the children using the learner workbook?

3. How does digital video making foster engagement and collaboration among learners using the workbook?

\section{Methods}

One school participated in the main study. The participating school had one grade 5 and one grade 6 class; both teachers and children participated in the LIVE project, which took place during the 2005-2006 school year. Due to the number of computers $(n=2)$ and video cameras $(n=2)$ available, it was not feasible to have all children working on videos at once. Instead, the classes were randomly divided into two halves; data were collected during the fall semester, when videos were made with the first half of pupils. In total, 17 pupils participated in the project, of which 10 were girls and 7 boys. The pupils worked in teams of 2-3 learners. Pupil teams were formed by the children themselves, in consultation with the teacher.

Refering to all three research questions, classroom observations and teacher interviews were conducted; additionally, learners completed a questionnaire at the end of the project. Semi-structured observations $(n=63)$ of pupil teams at work were carried out with the aid of an observation scheme containing seven open questions related to the lesson execution and recommendations for improving the material. It also contained 13 
questions in Likert-scale format pertaining to workbook use, learner attitudes and communication among the learners. In addition, data were collected through structured interviews with the two participating teachers and through learner questionnaires containing open and closed items, including analysis of the videos created by the other participating children.

The learner workbook was redesigned to be used by small groups with little to no instruction from the teacher. It contained seven modules, each intended to take 45 minutes. Because most Dutch primary schools use Windows $X P$, the workbook provided technical guidance for Windows MovieMaker - the video-making software that is embedded in this operating system. The activities in the modules are structured to stimulate learning of the aforementioned process-related knowledge and skills (pertaining to communication, collaboration and project management). The classic steps in message design are addressed through the seven modules:

1. Thinking about communication and a video topic

2. Writing the video script and planning the filming

3. Shooting the video

4. Capturing the video onto the computer

5. Editing and sequencing the clips

6. Adding effects: subtitles and transitions

7. Critical review of the draft video and creation of final version

The book also contains recommendations for a class movie festival in which the final products are reviewed. Figure 1 shows the title page from Module 7. Figure 2 shows a translation of the third activity cluster (page 3) from Module 1.

Les 7

De gemaakte video kritisch bekijken

\begin{tabular}{|l|l|}
\hline Hoelang duurt deze les? & 45 minuten \\
\hline Wat hebben jullie nodig? & - Computer waar jullie video op staat \\
& - Pen \\
\hline
\end{tabular}

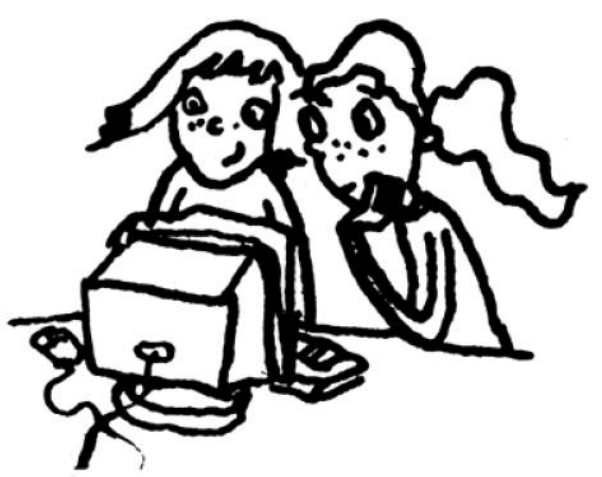

Figure 1: Title page from Module 7 


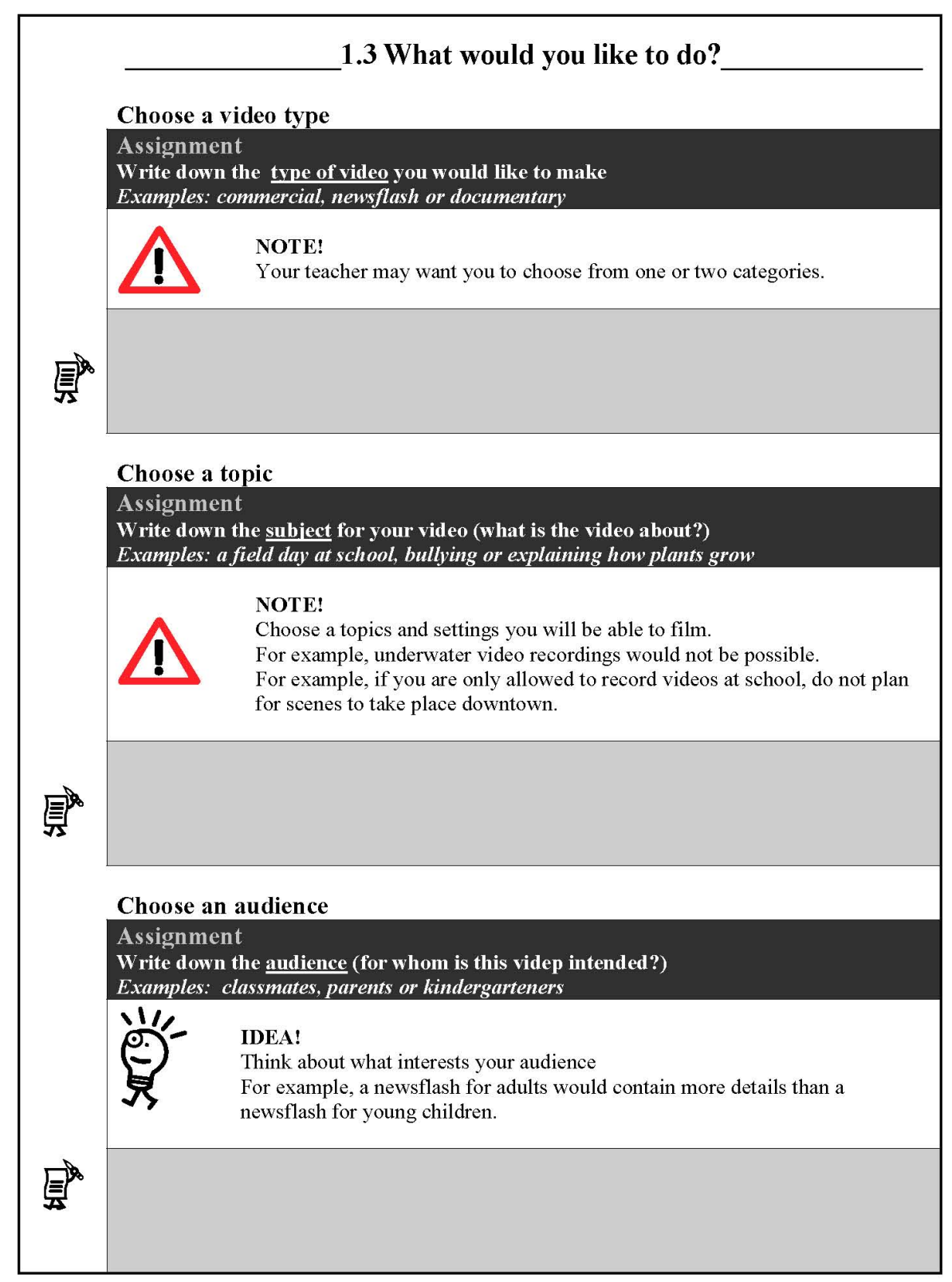

Figure 2: Translation of third activity cluster from Module 1

Following an introductory workshop, in which teachers became acquainted with the LIVE project, the software to be used, the teacher guide and the learner workbooks were given to the teachers. During the first two modules, a more active role was expected of the teachers. In these modules, teachers were to give instructions and evaluate the learner products (e.g. video storyboard). In Modules 3-7, the teacher role was limited; and learners were expected to work independently. During the concluding class movie festival, the teacher stimulated learners to discuss the video 
messages presented. Learners worked in nine teams of boys $(n=3)$ or girls $(n=5)$. One group was a mixed boy-girl team.

\section{Findings}

\section{Implementation of LIVE and use of the learner workbook}

An analysis of the observation data showed that the learners from class A used and understood the learner workbook better, than the students from class B. During the first two Modules in particular, the learners from group B only used the workbook every now and then, but not systematically. An overview of the results are presented in Table 1. Both teachers indicated that they perceived the workbook to be generally easy for children to use. Data from the learner questionnaire show that 11 students (mainly girls) were positive about the workbook, two students (boys) were neutral and four students (boys) did not like the workbook.

Table 1: Learner use and understanding of the learner workbook, per class ( $\mathrm{A}=5$ groups; $\mathrm{B}=4$ groups $)$ and per module

\begin{tabular}{|l|c|c|c|c|c|c|c|c|}
\hline & Class & $\begin{array}{c}\text { Topic } \\
\text { selection }\end{array}$ & $\begin{array}{c}\text { Script writing } \\
\text { and planning }\end{array}$ & $\begin{array}{c}\text { Shoot } \\
\text {-ing }\end{array}$ & $\begin{array}{c}\text { Captur- } \\
\text { ing }\end{array}$ & $\begin{array}{c}\text { Editing } \\
\text { clips }\end{array}$ & $\begin{array}{c}\text { Adding } \\
\text { effects }\end{array}$ & $\begin{array}{c}\text { Review and } \\
\text { final version }\end{array}$ \\
\hline \multirow{2}{*}{ Use workbook } & $A$ & 5.0 & 5.0 & 4.2 & 4.6 & 4.8 & 4.6 & 4.8 \\
\cline { 2 - 10 } & $B$ & 3.0 & 3.0 & 3.75 & 3.75 & 3.75 & 4.0 & 4.0 \\
\hline $\begin{array}{l}\text { Understand- } \\
\text { ing workbook }\end{array}$ & $A$ & 5.0 & 5.0 & 5.0 & 4.0 & 4.8 & 4.8 & 5.0 \\
\cline { 2 - 10 } & $B$ & 3.0 & 3.0 & 4.0 & 3.25 & 3.5 & 3.75 & 5.0 \\
\hline
\end{tabular}

Note: 5 point Likert scales: $1=--; 2=-; 3=+/-; 4=+; 5=++$

In addition to the use and understanding of the learner workbook, observation data were collected about the problems learners encountered when working with the workbook, the help they needed, and the time necessary to finish a module. In addition, information was collected about the extent to which the learning goals of the module were attained. Table 2 gives an overview of the results. The findings show that the pupils from class B encountered more problems and needed more help during the whole project. The differences between the two classes were bigger at the start than at the end of the LIVE project.

Table 2: Amount of problems, the need for help, the timing and the attainment of goals; per class ( $\mathrm{A}=5$ teams; $\mathrm{B}=4$ teams $)$ and per module

\begin{tabular}{|l|c|c|c|c|c|c|c|c|}
\hline & Class & $\begin{array}{c}\text { Topic } \\
\text { selection }\end{array}$ & $\begin{array}{c}\text { Script writing } \\
\text { and planning }\end{array}$ & $\begin{array}{c}\text { Shoot } \\
\text {-ing }\end{array}$ & $\begin{array}{c}\text { Captur- } \\
\text { ing }\end{array}$ & $\begin{array}{c}\text { Editing } \\
\text { clips }\end{array}$ & $\begin{array}{c}\text { Adding } \\
\text { effects }\end{array}$ & $\begin{array}{c}\text { Review and } \\
\text { final version }\end{array}$ \\
\hline \multirow{2}{*}{ Problems } & $A$ & 5.0 & 5.0 & 4.4 & 5.0 & 4.2 & 5.0 & 5.0 \\
\cline { 2 - 9 } & $B$ & 2.0 & 2.0 & 3.75 & 3.75 & 4.0 & 4.25 & 5.0 \\
\hline \multirow{2}{*}{ Needed help } & $A$ & 4.0 & 4.0 & 4.4 & 3.8 & 3.8 & 4.0 & 5.0 \\
\cline { 2 - 9 } & $B$ & 2.0 & 2.0 & 4.25 & 3.5 & 3.75 & 4.0 & 4.0 \\
\hline \multirow{2}{*}{ Timing } & $A$ & 2.0 & 2.0 & 4.4 & 5.0 & 4.2 & 4.6 & 5.0 \\
\cline { 2 - 9 } & $B$ & 2.0 & 2.0 & 5.0 & 5.0 & 4.0 & 4.75 & 5.0 \\
\hline \multirow{2}{*}{$\begin{array}{l}\text { Attainment of } \\
\text { goals }\end{array}$} & $A$ & 4.0 & 4.0 & 5.0 & 5.0 & 5.0 & 5.0 & 3.0 \\
\cline { 2 - 9 } & $B$ & 3.0 & 3.0 & 5.0 & 5.0 & 5.0 & 5.0 & 3.0 \\
\hline
\end{tabular}

Note: 5 point Likert scales: $1=--; 2=-; 3=+/-; 4=+; 5=++$

Timing was a problem, during the first two modules in particular. Both classes needed more time than was planned during the first two modules, but from the third module 
onwards, timing flowed more according to plan. The first module in class B took $3 \times 45$ minutes (instead of $1 \times 45$ minutes). The pupils from Class B also had more difficulty in attaining the learning goals of the first two modules compared to the pupils from class A. Class B had more difficulty concentrating than class A and the teacher indicated in the interview that he could offer less guidance to the children than planned. Additionally, he found the first two modules more difficult for the children, citing "the concept of communication" as very challenging. Module 7 (Review and Final Version) was somewhat problematic. This was mostly the case in Class B, where computers were close to each other and there was not enough room to sit two to a machine, thereby likely yielding a negative effect on learner concentration.

\section{Quality of the video messages}

Table 3 provides a brief narrative of the video messages that were created by the learners as part of the LIVE project. The average time of a video message was 3.19 minutes, which was close to the duration of the message that was asked for in the assignment.

Table 3: Overview of the video messages

\begin{tabular}{|l|l|}
\hline $\begin{array}{l}\text { The school } \\
\text { playground }\end{array}$ & $\begin{array}{l}\text { This video starts off with a quite and empty playground. The body of the } \\
\text { video shows children playing outside on the school playground; and zooms } \\
\text { in on specific games and conversations. It concludes with the message that } \\
\text { there are lots of fun things to do on the school playground. }\end{array}$ \\
Class A (3 girls) \\
\hline $\begin{array}{l}\text { Starting middle } \\
\text { school }\end{array}$ & $\begin{array}{l}\text { The video starts with a child saying what a big school this is compared to the } \\
\text { small elementary school. The child timidly enters the building and feels } \\
\text { embarrassed when she trips, bored in class, happy to meet a teacher, } \\
\text { disappointed when new people do not want to hang out with her. It } \\
\text { concludes with the message that middle school is very different, and warns } \\
\text { viewers to be prepared. }\end{array}$ \\
\hline Class A (2 girls
\end{tabular}




\begin{tabular}{|l|l|}
\hline $\begin{array}{l}\text { The bathroom } \\
\text { block }\end{array}$ & $\begin{array}{l}\text { This commercial-style video starts off with a title and then shows a girl who } \\
\text { needs to go to the bathroom. When she accidentally opens the door on } \\
\text { someone already in there, a girl steps in to introduce their handy-dandy } \\
\text { 'bathroom block' for avoiding this embarrassment and showing the name of } \\
\text { who is in the bathroom. After explaining and showing where it is sold, it } \\
\text { concludes back in the school with satisfied users. }\end{array}$ \\
\hline Laying eggs & $\begin{array}{l}\text { The video starts with 3 boys explaining that they are going to show the game, } \\
\text { "laying eggs." The boys demonstrate, while the cameraman narrates the } \\
\text { game, using instant replays and showing tricks. After the closing credits, this } \\
\text { video also shows the bloopers. }\end{array}$ \\
\hline
\end{tabular}

The video message was considered to have quality when it contained an introduction, a body and a conclusion. The video messages were evaluated on these components as well as the extent to which the video message adhered to the script. Also, camera use and sound control, editing of the clips and the layout (transitions/effects and titles) were evaluated. The results are presented in Table 4 . The video message analysis showed that all videos contain messages, some clearer than others. Five out of nine had both clear messages and easily recognisable introduction-body-conclusion structures. Two out of nine contained informational messages but not one singular message. Two thirds of the videos match the scripts written in first two lessons. A few groups made good use of the camera and edited the clips well (e.g. Starting middle school; Discrimination and The bathroom block). Only one video used the zoom function (Safety) or special camera positions (Starting middle school). Four out of the nine videos show little to no accounting for disturbing factors in the environment (e.g. screaming children in the schoolyard). All groups had quite a good layout, except that they all made too much use of effects.

Table 4: Quality of the video message, assessed by the researcher and by fellow pupils

\begin{tabular}{|l|c|c|c|c|c|c|}
\hline & Class & $\begin{array}{c}\text { Quality } \\
\text { message }\end{array}$ & $\begin{array}{c}\text { Conforms } \\
\text { to script }\end{array}$ & $\begin{array}{c}\text { Camera use and } \\
\text { sound control }\end{array}$ & $\begin{array}{c}\text { Clips } \\
\text { editing }\end{array}$ & Layout \\
\hline The school play ground & $A$ & 2.0 & 3.0 & 1.8 & 1.33 & 2.2 \\
\hline Starting middle school & $A$ & 3.0 & 2.0 & 2.6 & 3.0 & 2.2 \\
\hline Halloween & $A$ & 3.0 & 1.0 & 1.8 & 2.0 & 2.2 \\
\hline The news & $A$ & 2.0 & 3.0 & 1.8 & 3.0 & 2.2 \\
\hline Discrimination & $A$ & 3.0 & 3.0 & 2.2 & 3.0 & 2.2 \\
\hline The school blossoms & $B$ & 1.0 & 3.0 & 1.8 & 2.0 & 2.6 \\
\hline Safety & $B$ & 1.0 & 1.0 & 2.2 & 1.67 & 2.2 \\
\hline The bathroom block & $B$ & 3.0 & 3.0 & 2.2 & 3.0 & 2.6 \\
\hline Laying eggs & $B$ & 3.0 & 3.0 & 1.8 & 2.67 & 2.2 \\
\hline
\end{tabular}

Note: 1 = weak; 2 = neutral; 3 = strong

The learners were asked whether they understood the message that was conveyed in the video. Most learners found four videos easy to understand: Starting middle school (14 pupils found this easy), Discrimination (14 pupils); The bathroom block (11 pupils) and Laying eggs (11 pupils). Safety and Halloween were considered difficult by 12 and 7 pupils respectively. The school playground, The news and The school blossoms score in between. Both teachers were enthusiastic about the pupil products, which were above their expectations in terms of overall quality. In terms of message planning, 5 pupils found it difficult or very difficult to think of a topic; 6 were neutral and the rest said it was easy or very easy. Similar results were found for writing the script, though generally this was considered slightly less difficult. 


\section{Student engagement}

Observation and interview data showed the workbook activities to be generally engaging. Data on several aspects of student engagement were collected: active involvement, independent study attitude, interest, and on-task behaviour. In $73 \%$ of the sessions showed that pupils were actively participating in the module activities. Except for the first two lessons that proved problematic, $84 \%$ of the group observations showed pupils working independently; and both teachers confirmed this during the interviews. Despite active engagement, pupils only appeared to be genuinely interested during $62 \%$ of the sessions. However, they did remain calmly working on task, not disturbing others in $73 \%$ of the sessions. Significant differences were found between the two classes and between boy and girl groups. Tables 5 and 6 provide an overview of the results.

Table 5: Differences between the two classes in engagement during LIVE (M and SD)

\begin{tabular}{|l|c|c|c|c|c|}
\hline & \multicolumn{2}{c|}{ Class A } & \multicolumn{2}{c|}{ Class B } & \\
\hline No. of observations & \multicolumn{2}{|c|}{35} & \multicolumn{2}{c|}{4} & \\
\hline No. of groups & \multicolumn{2}{|c|}{5} & MD & SD & P \\
\hline & M & SD & 3.82 & 0.772 & $0.000^{*}$ \\
\hline Active & 4.63 & 0.731 & 3.82 & 1.090 & $0.001^{*}$ \\
\hline Independent & 4.57 & 0.502 & 3.86 & 0.932 & $0.001^{*}$ \\
\hline Interest & 4.60 & 0.812 & 3.21 & 1.258 & $0.000^{*}$ \\
\hline
\end{tabular}

Note: 5 point Likert scales: $1=--; 2=-; 3=+/-; 4=+; 5=++;{ }^{*} \mathrm{p}<0.05$

Table 6: Differences between boys and girls in engagement during LIVE (M and SD)

\begin{tabular}{|c|c|c|c|c|c|}
\hline & \multicolumn{2}{|c|}{ Boys } & \multicolumn{2}{|c|}{ Girls } & \\
\hline No. of observations & \multicolumn{2}{|c|}{21} & \multicolumn{2}{|c|}{35} & \\
\hline No. of pairs & \multicolumn{2}{|c|}{3} & \multicolumn{2}{|c|}{5} & \\
\hline & $\mathrm{M}$ & SD & MD & SD & $\mathrm{P}$ \\
\hline Active & 3.76 & 0.831 & 4.49 & 0,742 & $0.001^{*}$ \\
\hline Independent & 4.10 & 0.944 & 4.23 & 0.910 & 0.603 \\
\hline Interested & 3.57 & 0.926 & 4.60 & 0.736 & $0.000^{*}$ \\
\hline On task & 3.38 & 1.322 & 4.26 & 1.094 & $0.010^{\star}$ \\
\hline
\end{tabular}

Note: 5 point Likert scales: $1=--; 2=-; 3=+/-; 4=+; 5=++;{ }^{*} \mathrm{p}<0.05$

Students in Class A were more actively involved, were more independent and showed more on-task behaviour compared to the students from class B. The students from Class A also were more interested in digital video-making. The large standard deviation in class B on two aspects of engagement (an independent study attitude and on-task behaviour), implies that there are large differences between the groups in class B. From the observation and the interviews with the teacher of class B it became clear that particularly one boy group was often not on-task and asked a lot of questions, because they did not read the assignments in the work book. When girls and boys are compared, a significant difference in favour of girls was found for active involvement, interest and on-task behaviour. A large standard deviation was found for girls and boys for on-task behaviour. This implies large differences in on-task behaviour within the girl groups and the boy groups.

\section{Student collaboration}

Student collaboration was determined from two angles: collaboration within and between groups. The findings are presented in Tables 7 and 8. 
Table 7: Differences between class A and B in collaboration during LIVE (M and SD)

\begin{tabular}{|l|c|c|c|c|c|}
\hline \multicolumn{2}{|c|}{ Class A } & \multicolumn{2}{c|}{ Class B } & \\
\hline No. of observations & \multicolumn{2}{|c|}{35} & \multicolumn{2}{c|}{4} & \\
\hline No. of groups & \multicolumn{2}{|c|}{5} & MD & SD & P \\
\hline Collaboration within groups & 4.54 & 1.067 & 3.50 & 1.575 & $0.003^{*}$ \\
\hline Collaboration between groups & 2.40 & 1.397 & 2.11 & 1.166 & 0.378 \\
\hline
\end{tabular}

Note: 5 point Likert scales: $1=--; 2=-; 3=+/-; 4=+; 5=++;{ }^{*} \mathrm{p}<0.05$

Table 8: Differences between boys and girls in engagement during LIVE (M and SD)

\begin{tabular}{|l|c|c|c|c|c|}
\hline \multicolumn{2}{|c|}{ Boys } & \multicolumn{2}{c|}{ Girls } & \\
\hline No. of observations & \multicolumn{2}{|c|}{21} & \multicolumn{2}{c|}{35} & \\
\hline No. of pairs & \multicolumn{2}{|c|}{3} & MD & SD & P \\
\hline Collaboration within groups & 2.86 & 1.558 & 4.66 & 0.873 & $0.000^{*}$ \\
\hline Collaboration between groups & 1.86 & 1.014 & 2.66 & 1.392 & $0.026^{*}$ \\
\hline
\end{tabular}

Note: 5 point Likert scales: $1=--; 2=-; 3=+/-; 4=+; 5=++{ }^{*} \mathrm{p}<0.05$

No significant difference was found between the two classes for collaboration between groups. In general, teams did not help other teams very often. However the collaboration within groups was significantly stronger in class A compared to class B. Girls' groups collaborated better than boys' groups, and girls' groups were also more inclined to help other groups. During the interview, Teacher A was very enthusiastic about the collaboration within groups, particularly noting the negotiating, planning and communication that was stimulated within the groups. Teacher A viewed the consensus building as an important element of the project. In contrast, Teacher B felt that communication was not optimally stimulated through the project; saying that children are busy with too many aspects (writing a script, shooting the video, using the computer). On the questionnaires, $83 \%$ of the learners found collaboration within the group to be (very) easy; the rest were neutral on this aspect. As for between-group communication, this happened very little. That which did take place was more often in Class A.

\section{Discussion}

The studies described here were designed to explore how to facilitate the envisioned LIVE project activities, featuring digital video-making in primary school classrooms for the purpose of developing message design competencies. The findings show that the learner workbook was generally used in accordance with designer intentions, although the first two modules still require additional modifications to optimise timing and to better facilitate independent work. Learners worked independently, were interested and actively involved, particularly during the second two thirds when they were able to start working with the equipment. All groups persisted past initial struggles in project work; however, there was a tendency for all-girl teams to collaborate and remain on task better than all-boy groups. More than half of the video messages that were produced had good quality. Pupil perceptions on the level of difficulty to think of and produce an informative message vary, but tend to indicate a satisfactory match between challenges presented and ability levels. The study findings in Class B are generally less positive than in Class A. Factors possibly influencing this include: lower teacher enthusiasm, less instruction by the teacher; and more all-boy groups. 
Several limitations of this study should not be ignored in reflecting on the findings. First, the relatively small scale limits the generalisation of findings. The workbooks were tested in only two schools, and while each school met the three criteria for participation, they were very different schools. Besides not controlling for schoolrelated effects, teacher variables were also not taken into consideration. Another noteworthy limitation of the study pertains to the role of the researchers, who allowed themselves to become involved at the request of teachers and learners. While both of these limitations are explained by the choice to focus on optimising the supports and not on testing for generalisable effects at this stage, they indicate that the conclusions are only tentative.

As previously mentioned, the research described here relates to supporting the creation of digital videos in developing message design competencies. This study shows that, when introduced through a teacher workshop and supplemented with a teacher guide, the learner workbook is a feasible approach to supporting this process. Support for conducting the video-making activities is seen as a prerequisite to being able to study the learning gain of video-making activities in the language arts curriculum. While both teachers found the experience a positive one, only one of the two saw a clear added value for language arts in its current format. The other stated that it had potential, but it should be integrated into the language arts program used by the school. This view has also been reflected in research that has shown a major obstacle for integration being that fact that many technology applications are not explicitly aligned with the current curriculum and with the textbooks teachers use (Becker, Rawitz \& Wong, 1999; Cuban, 2001; Mumtaz, 2000; Voogt, 2003).

Now that process support is reasonably available, subsequent studies should be undertaken to explore more careful curricular integration as well as the learning gains resulting from participation in LIVE project activities. In so doing, explicit attention must be given to supporting learners in transferring the message design competencies developed while creating videos, to the design of verbal or printed messages. Such studies are not only needed to facilitate the LIVE project. At present, many teachers have received training in basic technology skills and knowledge, but hardly any continuing education that focuses on the pedagogical use of technology in instruction (Law, Pelgrum \& Plomp, 2008; Voogt, 2003).

Children are incredibly involved with written and verbal communication through modern technologies (film, photo, sound, games, etc.) but schools do little to capitalise on this (Kennisnet, 2005), despite dramatic improvements in the technological infrastructure of schools (Braam et al, 2003). Research on factors affecting curriculum implementation has pointed to the importance of involving teachers, to varying degrees, in shaping ICT-rich learning scenarios in their own classrooms (Ben-Peretz, 1990; Author, 2005; Sawyers et al., 2007). Further practice with the video-making activities would help individual teachers streamline their own processes, which would be necessary before teachers could realistically be expected to repeat the project without researcher presence or support.

When it comes specifically to managing and scaffolding the multiple layers in videomaking projects, Hofer and Owings-Swan (2005) note that this is particularly challenging for teachers, and call for researchers and practitioners to share their experiences so that we may harness the learning potential of digital video-making. Some examples of pedagogical uses of video-making are beginning to crop up, for 
example Cochrane and Bateman (2010) on mobile learning in tertiary education in New Zealand, but examples in primary education remain limited. Speaking to that call, the development phase of this project has yielded a research-based learner workbook and several implementation examples that may assist in the integration of video-making into the primary school language arts curriculum.

\section{Acknowledgments}

The authors would like to thank the participating schools and teachers for their cooperation and enthusiasm for this project. Further, we are grateful to student researchers and we also appreciatively acknowledge the contributions made by their mentors.

\section{References}

Anderson, M. (2002). The evolution of a curriculum: Yes, you can manage iMovie projects with 170 kids! Multimedia Schools, 9(4), 17-19.

http: / / www.infotoday.com/mmschools/sep02/anderson.htm

Babaszweski, T. (2002). Digital storytelling finds its place in the classroom. Multimedia Schools, 9(1), 32-35. http:/ / www.infotoday.com/MMSchools/jan02/banaszewski.htm

Ball, D. \& Cohen, D. (1996). Reform by the book: What is - or might be - the role of curriculum materials in teacher learning and instructional reform? Educational Researcher, 25(9), 6-8, 14 http: / / dx.doi.org/10.3102/0013189X025009006

Becker, H., Rawitz, J. \& Wong, Y. (1999). Teacher and teacher-directed student use of computers and software. Irvine: University of California.

BECTA (2004). What the research says about barriers to the use of ICT in teaching. Coventry: British Educational Communications and Technology Agency. [verified 16 Jul 2011]

http: / / www.mmiweb.org.uk/publications/ict/Research_Barriers_TandL.pdf

Bell, L. (2002). Preparing tomorrow's teachers to use technology: Perspectives of the leaders of twelve national education associations. Contemporary Issues in Technology and Teacher Education, 1(4), 517-534.

http:/ / www.citejournal.org/vol1 / iss4/ currentissues / general/ printarticle1.htm

Ben-Peretz, M. (1990). The teacher-curriculum encounter. Albany: State University of New York Press.

Braam, H., van Gennip, H., Wartenberg-Cras, F., Hoogenberg-Engbers, I., van der Neut, I., Sontag, L. \& Vreugdenhil-Tolsma, B. (2003). ICT in cijfers: Ict onderwijsmonitor schooljaar 2002-2003 [ICT in numbers: ICT-education monitor school year 2002-2003]. Onderwijsmonitor 2002-2003. http: / / www.ict-onderwijsmonitor.nl/

Burden, K. \& Kuechel. (2004). Evaluation report of the teaching and learning with digital video assets pilot. Coventry: BECTA. [verified 16 Jul 2011] http: / / www.beeit.co.uk/Guidance \%20Docs/Becta\%20Files / Reports\%20and\%20publications / 104\%20Teachi ng\%20and\%20learning\%20with\%20digital\%20video\%20assets\%202003-2004.pdf

Christi, A., Naish, V., Kelter, J., Pearman, C., Wycoff, W. \& Gender, J. (2004). Language arts comes alive as middle school learners become information producers. Meridian: A middle school computer technologies journal. [verified 16 Jul 2011] http: / / www.ncsu.edu/meridian/ win2004/laalive/4.html 
Cochrane, T. \& Bateman, R. (2010). Smartphones give you wings: Pedagogical affordances of mobile Web 2.0. Australasian Journal of Educational Technology, 26(1), 1-14.

http:/ / www.ascilite.org.au/ajet/ajet26/cochrane.html

Cuban, L. (2001). Oversold and underused: Computers in the classroom. Cambridge: Harvard University Press.

Dede, C. (2008). Theoretical perspectives influencing the use of information technology in teaching and learning. In J. Voogt \& G. Knezek (Eds), International handbook of information technology in primary and secondary education (pp. 43-62). http: / / dx.doi.org/10.1007/978-0387-73315-9_3

Greenwood, D. (2007). Have your students become the teacher and make an educational video for the class. Adobe Digital School Collection (ADSC). Retrieved from http://www.adobe.com/education/instruction/adsc/

Hernández-Ramos, P. (2007). Aim, shoot ready! Future teachers learn to 'do' video. British Journal of Educational Technology, 38(1), 33-41. http: / / onlinelibrary.wiley.com/ doi/10.1111/j.14678535.2006.00600.x/abstract

Hillocks, G. (1986). Research on written composition: New directions for teaching. Urban, IL: ERIC Clearinghouse on reading and communication skills. [verified $16 \mathrm{Jul} 2011 ; 8964 \mathrm{kB}$ ] http: / / www.eric.ed.gov:80/ERICWebPortal/contentdelivery/servlet/ERICServlet?accno=E D265552

Hillocks, G. (1999). Ways of thinking, ways of teaching. New York: Teacher College Press.

Hofer, M. \& Owings-Swan, K. (2005). Digital movie-making - the harmonization of technology, pedagogy and content. International Journal of Technology in Teaching and Learning, 1(2), 102110. http:/ / www.sicet.org/journals/ijttl/issue0502/Hofer.Vol1.Iss2.pdf

Hoffenberg, H. \& Handler, M. (2001). Digital video goes to school. Learning and Leading with Technology, 29(2), 10-15.

Hooper, S. \& Rieber, L. (1995). Teaching with technology. In A. Ornstein (Ed.), Teaching: Theory into practice (pp. 154-170). Needham Heights, MA: Allyn and Bacon.

Kearney, M. \& Schuck, S. (2006). Spotlight on authentic learning: Student developed digital video projects. Australasian Journal of Educational Technology, 22(2), 189-208. http:/ / www.ascilite.org.au/ajet/ajet22/ kearney1.html

Kennisnet (2005). Wat weten we over... taal en ict [What we know about... language and ICT]. Zoetermeer: Stichting Kennisnet Ict op School. [verified 16 Jul 2011] http: / / www.bereslim.nl/pdf/wat_weten_we_over_taal_en_ict.pdf

Knezek, G. A. \& Christensen, R. (2008). The importance of information technology attitudes and competencies in primary and secondary education. In J. Voogt \& G. Knezek (Eds.), International handbook of information technology in primary and secondary education (pp. 349-365). New York: Springer. 10.1007/978-0-387-73315-9_19

Law, N., Pelgrum, W. J. \& Plomp, T. (2008). Pedagogy and ICT use in schools around the world. Findings from the IEA SITES 2006 study. CERC Studies in comparative education. Hong Kong: Comparative Education Research Centre, The University of Hong Kong, and Dordrecht: Springer. 
Lee, M., McLoughlin, C. \& Chan, A. (2008). Talk the talk: Learner generated podcasts as catalysts for knowledge creation. British Journal of Educational Technology, 39(3), 501-521. http:/ / onlinelibrary.wiley.com/ doi/10.1111/j.1467-8535.2007.00746.x/ abstract

Levin, H. (2003). Making history come alive. Learning and Leading with Technology, 31(3), 22-27. [verified 16 Jul 2011] http:/ / www.howardlevin.com/download/iste-11-03.pdf

McKenney, S. (2005). Technology for curriculum and teacher development: Software to help educators learn while designing teacher guides. Journal of Research on Technology in Education, 28(2), 167-190. http: / / business.highbeam.com/619/article-1G1-139837109/technologycurriculum-and-teacher-development-software

Mumtaz, S. (2000). Factors affecting teachers' use of information and communications technology: A review of the literature. Journal of Information Technology for Teacher Education, 9(3), 319-342. http: / / dx.doi.org/10.1080/14759390000200096

Nystrand, M., Gamaron, A., Kachur, R. \& Prendergast, C. (1997). Opening dialogue: Understanding the dynamics of language and learning in the english classroom. New York: Teachers College Press.

Olson, J. (2000). Trojan horse or teacher's pet? Computer and the culture of the school. Journal of Curriculum Studies, 32, 1-8. http: / / dx.doi.org/10.1080/002202700182817

Peterson, S. (2003). Peer response and students' revisions of their narrative writing. Educational Studies in Language and Literature, 3(2), 239-272. 10.1023/B:ESLL.0000003605.45224.b5

Prawatt, R. \& Floden, R. (1994). Philosophical perspectives on constructivist views of learning. Educational Psychologist, 29(1), 37-48. http:/ / dx.doi.org/10.1207/s15326985ep2901_4

Reid, M., Burn, A. \& Parker, D. (2002). Evaluation report of the British educational communications and technology agency digital video pilot project. Coventry: BECTA. [verified 18 Jul 2011] http: / / eprints.ioe.ac.uk/4253/1/Burn_2002_Digital_Video_report.pdf

Sawyers, L., Bryk, A., Fountas, I., Pinnell, G., Scharer, P. \& Walker, L. (2007, April). Transforming teacher learning through design activity: Creating a web-based professional development support system for video case-based professional learning. Paper presented at the American Educational Research Association, Chicago. [verified 18 Jul 2011] http:/ / www.teachscape.com/html/ts / nps/research/PDS2_Design_Paper_AERA07.htm

Schuck, S. \& Kearney, M. (2006). Capturing learning through student-generated digital video. Australian Educational Computing, 21(1), 15-20. http: / / acce.edu.au/journal/21/1/ capturinglearning-through-student-generated-digital-video

Shewbridge, W. \& Berge, Z. (2004). The role of theory and technology in learning video production:The challenge of change. International Journal on E-Learning, 3(1), 31-39. http: / / www.highbeam.com/doc/1G1-116143486.html

SLO (2007). Taalonderwijs [Language education]. Taalsite. [verified 18 Jul 2011] http: / www.slo.nl/primair/leergebieden/ned/taalsite/lexicon/

Sperling, M. (1996). Revisiting the writing-speaking connection: Challenges for research on writing and writing instruction. Review of Educational Research, 66(1), 53-86. http: / / dx.doi.org/10.3102/00346543066001053

Theodosakis, N. (2002). How digital filmmaking develops higher-order thinking skills. Virginia Society for Technology in Education Journal, 16(2), 21-24. 
Thijs, A. (1999). Supporting science curriculum reform in Botswana: The potential of peer coaching. Unpublished doctoral dissertation, University of Twente, Enschede.

van den Akker, J. (1998). The science curriculum: Between ideals and outcomes. In B. Fraser \& K. Tobin (Eds.), International handbook of science education (pp. 421-447). Dordrecht: Kluwer Academic Publishers.

van den Akker, J. (1999). Principles and methods of development research. In J. van den Akker, R. Branch, K. Gustafson, N. Nieveen \& T. Plomp (Eds.), Design approaches and tools in education and training (pp. 1-14). Dordrecht: Kluwer Academic Publishers.

van den Ven, P. (1993). Schrijven als sociaal proces [Writing as a social process]. MOER, 1, 2-12.

Voogt, J. (1997). Courseware in onderzoekend natuurkunde-onderwijs: Een implementatie perspectief [Courseware in inquiry-based learning: An implementation perspective]. Pedagogische Studiën, 74(2), 130-141.

Voogt, J. (2003). Consequences of ICT for aims, contents, processes and environments of learning. In J. van den Akker, W. Kuiper \& U. Hameyer (Eds.), Curriculum landscapes and trends. Dordrecht: Kluwer.

Windschitl, M. (1998). The WWW and classroom research: What path should we take? Educational Researcher, 27(1), 28-33. http:/ / dx.doi.org/10.3102/0013189X027001028

Wong, B. \& Berninger, V. (2004). Cognitive processes of teachers implementing composition research elementary, middle, and high school classrooms. In B. Shulman, K. Apel, B. Ehren, E. Silliman \& A. Stone (Eds.), Handbook of Language and Literacy Development and Disorders (pp. 600-624). New York: Guilford.

Authors: Susan McKenney and Joke Voogt

Department of Curriculum Design \& Educational Innovation

Faculty of Behavioral Sciences, University of Twente

PO Box 217, 7500AE, Enschede, The Netherlands

Email: susan.mckenney@utwente.nl,j.m.voogt@utwente.nl

Please cite as: McKenney, S. \& Voogt, J. (2011). Facilitating digital video production in the language arts curriculum. Australasian Journal of Educational Technology, 27(4), 709726. http:/ / www.ascilite.org.au/ajet/ ajet27/ mckenney.html 